\title{
Shakespeare and the wandering mind
}

\author{
Raphael Lyne
}

Shakespeare Lecture, read on 18 May 2018.

Abstract: Cognitive scientists are beginning to explore the important work our minds do when attention wanes. In particular, it seems that orientation of the individual in relation to past, present, and future may be developed and maintained during periods of distraction. Shakespeare works with the potential for productive mind-wandering in characters and in audiences. In Henry $V$, they and we think beyond present business into the ideologies and costs of the underlying plans and possibilities. The King himself embodies the interaction of wandering and selfhood. In Much Ado About Nothing the friends and audience of Beatrice and Benedick may not be fully absorbed by their witty exchanges; there is another story to be told, in the gaps Shakespeare creates in the action of the play, in which they end up taking their inevitable roles as lovers.

Keywords: Shakespeare, attention, distraction, mind-wandering, Henry V, Much Ado About Nothing.

Note on the author: Raphael Lyne is Professor of Renaissance Literature in the Faculty of English at the University of Cambridge, and a Fellow of Murray Edwards College. $\mathrm{He}$ is the author of four books, including Shakespeare, Rhetoric and Cognition (CUP, 2011) and Memory and Intertextuality in Renaissance Literature (CUP, 2016), and the editor (with Cathy Shrank) of The Complete Poems of Shakespeare (Routledge, 2017). rtr1100@cam.ac.uk

(C) The author(s) 2020. This is an open access article licensed under a 
Shakespeare makes us think about how we think. He makes our minds work in interesting and unexpected ways, and he opens that work up to scrutiny. Here the focus is on how Shakespeare draws out the things our minds do when they wander. There are inevitably moments when audience members do not maintain full attention on the action and language of a play; some scenes and speeches are more conducive to this than others. There are also moments when onstage minds seem to be busy elsewhere, not focused on what we can see and hear. Such moments are illuminated by emerging thinking in cognitive science that suggests human minds do a lot of important work while wandering. Shakespeare's acute interest in this is consistent with his varied roles in the theatre: having stood himself in front of a watching crowd, he must have been an avid student of attention and its opposites. Working with the scientific framework helps refine an understanding of how Shakespeare's plays work, and it also reveals how rich and subtle his understanding of cognition - both of his characters and of his audiences - can be. So the turn towards cognitive science aims towards insights in two directions: a nuanced reading of features of the plays, and a better appreciation of the expertise, insight, examples, and hypotheses, that literature can offer to the interdisciplinary study of the mind.

A moment in The Tempest illustrates the vitality of mind-wandering as it arises in drama. When Prospero reveals to Miranda the story of her childhood and exile, he urges her repeatedly to pay attention. 'I pray thee mark me', he says more than once; 'Dost thou attend me?'; 'Thou attend'st not'; 'Dost thou hear?' (1.2.67 and 88, 78, 87, 106 , respectively). ${ }^{1}$ Shakespeare may be portraying a realistic and sharp-edged fatherdaughter interaction (he does go on; she does drift off). He may also be parodying his own flagrant act of convenient exposition (this is how he tells his audience the backstory). A psychologically nuanced account might find more interest in Miranda's apparent distraction here. She may be experiencing wonder that comes across to her father as vacancy, but it may also be that she needs moments of absence to process what she is hearing into her personal narratives of past, present, and future. What she makes of this information is to some extent hers alone, and this proves challenging to her father, who typically seeks to control the thoughts of others. We may see something comparable to this in Caliban's dreams, and in Prospero's concern when he loses track of his revolt with Stephano and Trinculo; we may see it in Ariel's yearning for freedom; we don't see what is going on as Antonio broods. In all these cases, what is comparable is that Prospero is wary of divergent mental work, pressing characters back into line, pushing them towards attention, sometimes in vain.

\footnotetext{
${ }^{1}$ All quotations from and references to Shakespeare are from The Riverside Shakespeare, 2nd edition, ed. G. Blakemore Evans et al. (1997).
} 
Mind-wandering as a literary concern has been explored in relation to a variety of literature. It tends to overlap with another, more negatively inflected antonym to attention, namely distraction. This topic has been explored in Natalie Phillips's book Distraction: Problems of Attention in Eighteenth-century Literature. ${ }^{2}$ Her emphasis is on fading and drifting attention, as a problem in and around literature, but also as something that finds kinds of validity (because it enables creativity, and tends against fixation) in novels. Lily Gurton-Wachter has reached some overlapping conclusions when addressing Wordsworth. In his writings, she argues, it seems that tuning in to the latest, newest things of importance, and gaining access to an artistic response to them, require a relaxation of attention. ${ }^{3}$ Distraction is attributed some positive qualities in Alice Bennett's study of 21st-century novels: rather than being symptomatic of an age of attention-crisis, she sees these novels as sharply and subtly engaged in questioning assumptions about the virtues of maintaining and losing focus. ${ }^{4}$ These writers all find reasons why the problems of attention they encounter are rooted in specific cultural and historical contexts. Important though these are - and they are matched by frameworks particular to Shakespeare's environment - it seems likely that the positives and negatives of slackening one's engagement in the here and now are a recurring, and more or less inevitable, feature of the relationship between human beings, societies, and the world beyond.

Michael Wood's essay on the topic also gives some pertinent prompts for thought. For Wood, 'only something like the concept of distraction will catch the contours of our experience in all kinds of reading'. ${ }^{5}$ A model of reading based only on what is gained by being attentive is a limited one. He indicates three areas where the positive results of distraction could be claimed. The first is puns (as in his example, James Joyce's Finnegans Wake). They are a 'small-scale working model of the whole process of making multiple meaning', and in order to act as such they draw us away from the present occasion, letting our minds flow. The second is genre: the idea is that a degree of distraction from manifest stimuli is required for the underlying patterns to impinge. This applies pretty well to Henry $V$ and Much Ado: there is a shape of history, and a shape of comedy, that might be occluded in all the details and moments, but a sort of distracted openness may receive their signals. The third of Wood's instances of beneficial distraction applies to excessive style. His example here is Cormac McCarthy's Blood Meridian. Distraction leads to immersion; attentiveness (Wood argues) cannot stomach 'more or less unreadable passages on every other page', and thus misses out on the chance to experience the novel fully. There

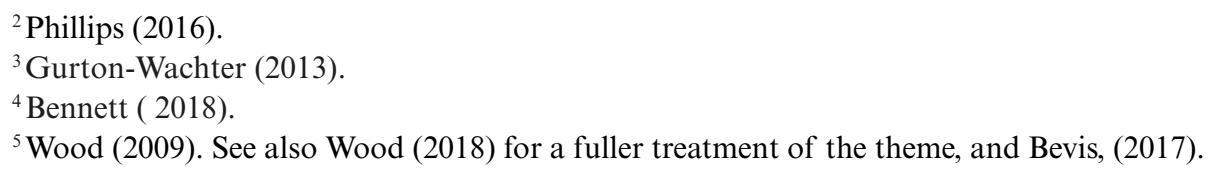


could be a parallel here with moments saturated with horror in Shakespeare's Lucrece, or Titus Andronicus, or King Lear.

Modern cognitive science is turning to phenomena relating to mind-wandering. It is increasingly recognised that attention is a crucial aspect of consciousness; indeed, it may be fundamental to it. ${ }^{6}$ It is also increasingly recognised that there must be strong reasons for the huge amount of brain activity devoted to matters other than the input of sensory stimuli and the output of actions. Mind-wandering, then, a positive version of the more negative distraction, is a topic of great interest. This kind of mental work might only look like, or feel like, a diversion. Sometimes we start thinking about family, or snacks, or travel plans, and perhaps some of the time that is all there is. But alongside these things that our metacognition (our ability to inspect the contents of consciousness) can reach, there are other things going on, patterns of thought that do important work for us.

This is a developing orthodoxy among some influential cognitive scientists. Michael Corballis gathered some of the key trends in the field in his book The Wandering Mind. ${ }^{7}$ Mind-wandering is seen as an activity that is intimately associated with a variety of mental operations: dreams, hallucinations - perhaps quite predictable things - but also planning, processing memories, understanding ourselves as selves, storytelling, and creativity, have all been seen as things to which mindwandering contributes. A positive view of daydreaming, for example, might see it as a way in which we tell stories of the world with us in the middle, a way in which we make sense of experiences new and old in a particularly important way, which is what they mean to us. Thinking about what is for lunch, the sort of thing we might most readily do when our minds wander, is only a small, accessible, part of something much larger, a sign that there is ongoing work beyond our reach, organising our experiences around stories of ourselves. (And in evolutionary terms, surely, a tendency for the mind to keep surreptitious track of the lunch situation is not a bad adaptation.) The brain regions associated with this work are often known as the 'Default Mode Network': a network because there are several, and 'default mode' because there is activation in these regions when subjects are not engaged in any particular activity. (It needs to be said that, while the Default Mode Network is often discussed by cognitive scientists, there are others who counsel against placing too much stress either on its special association with mind-wandering, or on its discreteness as a network, given its many interconnections. ${ }^{8}$ )

\footnotetext{
${ }^{6}$ See Watzl (2017).

${ }^{7}$ Corballis (2015).

${ }^{8}$ See, respectively, Gilbert et al. (2017) and Fornito et al. (2012).
} 
When we drift away for a moment, or longer, from full attention to a Shakespeare play, we submit more to these essential processes. A playwright might actually benefit from such mind-wandering. Whether watching or reading, those encountering a play should focus on it, but perhaps they also need to have their minds divert, with or without awareness of the wandering, to work out how it relates to them, ideally by telling a little story inwardly about why they like it, learn from it, understand it, and so on. Travels in time and space are characteristic of mind-wandering, but this is not a matter of dispersal; rather, it is about a kind of maintenance, putting knowledge and experiences in contact with memories, plans, and narratives of the self. Research continues into the field. One key question relates to the coherence of the concept: is it so heterogeneous that it cannot hold together?' Other scholars are interested in the proportion that is deliberate: of course sometimes we initiate a drifting-away of focus because we are doing something boring. Is there a sharp dividing-line between this and the unintentional kind? ${ }^{10}$ In another study the focus is on the 'metacognitive' aspect of mind-wandering: the extent to which we can inspect the contents of our excursions. ${ }^{11}$

In general, the drift is towards a new understanding of how apparent diversions (daydreaming, for example) and apparent core business (selfhood, for example) are related. This has a bearing on how we think about the interaction of characters, but perhaps most of all on how we think about our own mental work as we watch or read a play. Acknowledging that attention is liable to lapse to some extent need not simply be an admission of a tendency towards failure. Such fluctuations could be a positive or necessary contributor to the experience of literature. It is especially interesting to consider how a play or a poem or a novel might dare to work with this counterintuitive part of its effect on us. Can we catch texts making us or letting us wander mentally, inviting us to consider the causes, contents, and consequences of that wandering?

There are some difficulties here. One is revealed by the invocation of the 'we' of audience experience: this should be taken, in this essay, as a wary attempt to offer a persuasive account of how plays are designed to tend to work, rather than a concrete statement of standard or inevitable effects that would apply uniformly to all. References to 'the audience' in the third person have a similarly limited aspiration, accepting person-by-person, minute-by-minute variation, but hoping still to give a plausible description of what those attending make of drama together, and vice versa. Furthermore, the emphasis on the audience does not mean that the argument of this essay is only aimed at plays in performance. Although the theatre is a place where the

\footnotetext{
${ }^{9}$ Hao-Ting Wang et al. (2017). See also Callard et al. (2013).

${ }^{10}$ Seli et al. (2016).

${ }^{11}$ Schooler et al. (2011).
} 
ebbs and flows of attention may be especially palpable, nearly all the points here can be taken to apply to readers as well.

It may also be difficult to expect or assume much coherence between the characteristics of early modern attention, as explored in the Shakespearean theatre, and the ones being explored in recent experiments. Nevertheless, in various ways there are strong reasons to believe that this is not only a recent phenomenon. Montaigne, well known to be a vital influence on Shakespeare, portrays the human mind, and particularly his own mind, wandering in both negative and positive ways. When he turns inward, he often observes the curious origins and directions of thoughts, and the mobility of mental focus:

Fewe entertainements then, staye me without vigour and force. T'is true that courtesie and beautie possesse me, as much or more, then waight and deapth. And because I slumber in all other communications, and lend but the superficiall parts of my attention unto them, it often befalleth me, in such kinde of weake and absurde discourses, (discourses of countenance) to blurt out and answer ridiculous toyes, and fond absurdities, unworthie a childe; or wilfullie to holde my peace; therewithall more foolishly and incivilye. I have a kind of raving fancie-full behaviour, that retireth me into my selfe; and on the other side, a grosse and childish ignorance of many ordinarie things; by meanes of which two qualities, I have in my dayes committed five or sixe as sottish trikes, as any one whosoever; which to my derogation may be reported. ${ }^{12}$

Here, as so often, Montaigne is self-deprecating, but there is always a serious purpose when he invites laughter or scorn at his foibles. He finds his mind fascinating in all its manoeuvres, and implicitly at least makes the case that all these manoeuvres are vital to, or at least integral to, its achievements. He would not be himself without his capacities or his fallibilities.

Even without direct parallels for the interest in selfhood, memory, and future planning asserted by the modern science of mind-wandering, Montaigne represents a telling example of the presence of some aspects of the field in renaissance thought. Other examples could be cited. Robert Burton's Anatomy of Melancholy arises, like Montaigne's essays, at the intersection of philosophy, psychology, scepticism, and boundless intertextuality. ${ }^{13}$ Its advice about how to avoid and manage melancholy includes various kinds of mental discipline, but the work itself takes a wandering path, and derives some sort of energy, pleasure, or relief from these elliptical cognitive pathways. One of the most interesting fields in which an early modern anxiety about attention surfaces is religion. While pious observance is superficially consistent with

\footnotetext{
${ }^{12}$ Michel de Montaigne, The Essayes or Morall, Politike and Millitarie Discourses (1603). See also the essays 'Of Exercise or Practise' (II.6, T5v-V2v), 'Of Repenting' (III.2, 2S5r-2T2v), 'Of Three Commerces or Societies' (III.3, 2T2v-2T5r; the quotation comes from this essay), 'Of Experience' (3.13, 3H1r-3K4v). On reading Montaigne and the mind in Montaigne, see Cave (2007: 7-17).

${ }^{13}$ Burton (1621).
} 
avid attentiveness, God and Faith were not accessible to worldly senses, so the Christian path had to be open in some way to mental diversion (but only the right kind of diversion). David Marno's study of John Donne describes the special forms of religious attention that arose in this complex framework. ${ }^{14}$

Problems of attention extend into the early modern theatre, which is generally seen as a distracting and distractable environment. Andrew Gurr, for example, focuses on the liveliness of audience behaviour; while this relates most of all to tangible distractions, rather than inwardly generated diversions, we still have to imagine audiences in fluctuating relationships to plays. ${ }^{15}$ Evelyn Tribble is interested in the direction rather than the maintenance of attention, but her account of the early modern theatre allows for significant continuities between the cognitive operations of audiences now and then. ${ }^{16}$ Kent Cartwright infers the experience of audience members from the way play-texts seem to expect them to behave. He describes "how plays invite a rhythm of "engaged" and "detached" responses from the audience'. ${ }^{17}$ This refers to dynamics of distance and self-awareness, consciousness of illusion versus immersion. Earlier scholars, then, have in various ways treated attention and distraction in Elizabethan and modern audiences as comparable, even while allowing for a range of contextual differences. In keeping with this, invoking 'the audience' in this essay aims to speak to both past and present.

As Anthony Dawson and Paul Yachnin show, there can be a political aspect to questions of attention. As they consider whether the Shakespearean theatre should be thought of as a place of shared or separate experience, they are interested in how a turn away from where one is supposed to be looking might be an act of resistance. ${ }^{18}$ Walter Benjamin and Theodor Adorno are the crucial forerunners of discussions of the politics of distraction in modern criticism. Benjamin introduces a set of positive implications. Is attention necessarily what is required of the modern political subject? Perhaps, in relation to art, not:

Distraction and concentration form polar opposites which may be stated as follows: A man who concentrates before a work of art is absorbed by it. He enters into this work of art the way legend tells of the Chinese painter when he viewed his finished painting. In contrast, the distracted mass absorbs the work of art. This is most obvious with regard to buildings. Architecture has always represented the prototype of a work of art the reception of which is consummated by a collectivity in a state of distraction. ${ }^{19}$

\footnotetext{
${ }^{14}$ Marno (2016).

${ }^{15} \operatorname{Gurr}(1987,2009)$.

${ }^{16}$ Tribble $(2011,2015)$.

${ }^{17}$ Cartwright (1991).

${ }^{18}$ Dawson \& Yachnin (2001).

19 Benjamin (1999: 232). See also North (2011).
} 
Adorno writes more negatively about what seems like a modern disease of distraction, taking a different view about the political ethics of attentiveness. ${ }^{20}$ However, for Benjamin, there are new art forms that afford opportunities to the distracted modern viewer. Film is cited as a key example; it responds best of all to partial attention, in Benjamin's account. He is building a counter-intuitive validation of the value of the wandering mind in changing cultural circumstances:

The distracted person, too, can form habits. More, the ability to master certain tasks in a state of distraction proves that their solution has become a matter of habit. Distraction as provided by art presents a covert control of the extent to which new tasks have become soluble by apperception.

This idea of absent-minded examination is resonant beyond the context Benjamin aims to describe. It might hint at how the viewer of Shakespearean drama, now and then, is only partly composing a response consciously, because there are pressures and drifts involved that exert considerable influence.

Jonathan Baldo's essay on Shakespeare and distraction traces the BenjaminAdorno, freedom-bondage opposition, starting with Pascal's observation that while distraction is a source of misery, it also acts as a consolation for that misery. ${ }^{21} \mathrm{He}$ mentions Puritan fears that theatre itself was a distraction from godliness; from a very different direction (as has been seen) Montaigne must have offered Shakespeare, at some point in his career, models of what happened if you followed the mind as it wandered. Baldo's argument is that 'his plays are constructed in such a way as to demonstrate the ethical value of distraction', because of, especially in relation to Hamlet, 'the ethical advantages of periodic experiences of a distracted self and suspended agency over the ghostly call to the deathly steadfastness of fixed judgments and unerring courses' (140). In these particular circumstances, goal-oriented focus is monstrous. This note is generalised somewhat by Christopher Pye:

Distraction is also, for Shakespeare, what saves, unbinding the self from solipsistic closure on the one hand and object fixation on the other. The indeterminate character of that state-salvific, but only insofar as it is without object or aim; a betwixt-andbetween moment that is also a habitable condition-leads to the intuition that Shakespeare articulates in such moments the condition of aesthetic subjectivity as such: distraction concerns art in a significant key.22

Again there is the powerful idea that the exclusionary nature of attention is dangerous, and the directionless quality of distraction provides an antidote - it is 'salvific'. The

\footnotetext{
${ }^{20}$ See Adorno (2001).

${ }^{21}$ Baldo (2014), quoting Pensées 128.

${ }^{22}$ Pye (2015: 1).
} 
sense that a release from attention might be liberating is rather different from the psychological emphasis outlined above. In the plays to which this essay now turns, more will be made of the ways in which our wandering minds might tend to tell stories of ourselves past, present, and future, and how crucial these may be. Nevertheless, the sense of liberation will not be entirely absent. One reason for this is that the shifts of attention we see in characters, and the shifts of attention that are made possible for audiences, are not the same things, and need not even be synchronised. We may find room to drift away while characters are avid; we may watch carefully as they lose focus. Such mismatches may themselves give a sense of liberation, a sense that theatre's hold on us, and social life's hold on us, are dynamic and complex.

In the second scene of Henry $V$ the King and his counsellors are given a learned justification of war in France, based on the Salic Law relating to succession through the female line. Peter Lake's view of this passage, at one extreme, is that 'the archbishop's statement of the King's case is so complex and convoluted as to be entirely unintelligible in performance and extremely difficult to follow on the printed page' ${ }^{23}$ It does seem that Shakespeare has presented the detail thickly:

Nor did the French possess the Salique land

Until four hundred one and twenty years

After defunction of King Pharamond,

Idly suppos'd the founder of this law,

Who died within the year of our redemption

Four hundred twenty-six. (1.2.56-61)

In a chronicle, numbers give structure and make things easier to follow; here that effect is only vestigial, and instead the versified numbers and names, alongside the savoured technicality of words like 'defunction', tend towards confusing complexity. It may be necessary to assume a difference between modern and early modern experiences of the scene. In the introduction to his edition of the play, Gary Taylor defends the speech against charges of obscurity, arguing that an Elizabethan audience would have been able to see the point of its dynastic subtlety, since they took monarchic theory seriously, and they were accustomed to learned sermons tracing complex trajectories. ${ }^{24}$ Nevertheless, it has often seemed to be a speech to steer around or get through, and it is hard to believe that this is only a recent phenomenon. Anthony Dawson

\footnotetext{
${ }^{23}$ Lake (2016: 366).

${ }^{24}$ Gary Taylor (2008: 34 40. Taylor cites Axton (1977), for the observation that the same justification applied to the succession of James I to the English throne.
} 
is surely right to say that it is a 'cheap trick to make comic game out of the whole matter', but the temptation to win a laugh here or there has often been taken. ${ }^{25}$ The scene overall is tensely anchored by the King's threatening precision, and it is animated by the multiplicity of perspectives. The expressions of onstage observers may be hard to read; it may not be obvious what they are thinking about the key questions in the air, which revolve around how the King will respond, and what inflection there is in his question 'May I with right and conscience make this claim?' (1.2.96).

When Adrian Lester played the role of the King in 2003, the Iraq war, and the controversy over the case made for invasion, gave this scene additional edge. As Lester sees it, 'Henry hasn't decided', and 'as he's [that is, the archbishop] speaking, and most of the others find it hard to follow, Henry is concentrating, sometimes listening hard, sometimes thinking. ${ }^{26}$ There are various ways in which that 'thinking' could be taken. It could be that this is another form of engagement, a conscious logical response to the things he is hearing. It could also suggest (and the two are not mutually exclusive) a wider ranging set of thoughts about the soldiers who will die, his own role, his kingship, and so on. Some of these might count as mind-wandering. Shakespeare has created a scene in which the King's reactions could be more of an object of focus for other characters, and for the audience, than the speaker; indeed, every onstage figure's thoughts could deserve our attention. As the archbishop recites his dossier, what really matters is the way it strikes the listeners, and how they see themselves, in the past, present, and future, in relation to it. From the limited amount we know of early modern acting styles, it may be difficult to extrapolate back from modern techniques, in which the act of listening, as much as the act of speaking, is done in character; but it seems very likely that the actors' work did not finish when they stopped speaking. ${ }^{27}$ The speech is shaped to allow our minds to drift towards thinking about where the minds of onstage listeners may be drifting, which is a sharp-edged dramaturgical ploy.

The Prologue of Henry $V$ famously asks the audience to do more than just attend: they have a job to do, filling things out beyond the limitations of the stage. One of the things to be filled out is the nation itself, and here the cooperative work done by the theatre audience shadows the work of belief and consent that underlies nationhood itself (in the play and beyond). We may be conscious of participating in the play's political storytelling, but mind-wandering may also be involved, especially when it concerns the relationship of the individual to the larger group. Critics of Henry $V$ have worked on the complexity of its politics for a long time, and have often come close to inferring mental work behind the scenes. An understated but resonant

\footnotetext{
${ }^{25}$ Dawson (1988: 120).

${ }^{26}$ Quoted in Smallwood (2004: 150).

${ }^{27}$ See Palfrey \& Stern (2007: 74-5). For a recent account of the particular skills of the early modern actor, see Tribble (2017).
} 
forerunner of this way of thinking came in Norman Rabkin's evocation of the rabbit/ duck optical illusion to capture the ambivalence of the play about authority figures, and the 'inscrutability of history' ${ }^{28}$ Phyllis Rackin's landmark book Stages of History wove together ideological problems, tensions, anachronism, subversion, patriarchy, contested causation, theories of history, polyphony, and contradiction. ${ }^{29}$ Stephen Greenblatt, in another landmark study, offered a more constrained depiction of the political energy in Henry $V$ :

The audience's tension ... enhances its attention; prodded by constant reminders of a gap between real and ideal, the spectators are induced to make up the difference, to invest in the illusion of magnificence, to be dazzled by their own imaginary identification with the conqueror. The ideal king must be in large part the invention of the audience, the product of a will to conquer that is revealed to be identical to a need to submit. ${ }^{30}$

For Greenblatt, the audience may be responsible for the 'invention' of royal power, but it is compelled, or at least 'induced' to do so. Not all critics feel that the play, or Shakespearean drama in general, leaves the wandering mind with so little room to manoeuvre. Imagined communities are not always unified, especially when efforts to create them are as visible as they are in Henry $V^{31}$

Recent criticism has portrayed, if not mind-wandering, more nebulous patterns in which thoughts of the nation circulate. In particular, patriotic thinking has been seen in relation to, and as a product of, memory. Alison Thorne describes 'the embryonic discourse of national solidarity' in the history plays generally, which emerges from an older order. ${ }^{32}$ Rebecca Warren-Heys has written about the way that memories are made in the play, in various senses: powerfully dramatic scenes construct things that are memorable for the audience but also condition the ways that onstage characters see the world. ${ }^{33}$ For Philip Schwyzer the production of national feeling in Henry's speeches and in the play is a matter of conjuring up ghosts: the spectral past of England is invoked as if by magic. ${ }^{34}$ Finally, Jonathan Baldo recognises that national

\footnotetext{
${ }^{28}$ Rabkin (1977).

${ }^{29}$ Rackin (1990). Woodcock (2008) has a comprehensive and astute narrative of the critical history of the play.

${ }^{30}$ Greenblatt (1988: 63). See also McEachern (1996).

${ }^{31}$ The echo of the title of Benedict Anderson's Imagined Communities: Reflections on the Origin and Spread of Nationalism (1983) is intentional; this book's depiction of community as something that cannot be tangibly experienced or verified has been very influential (on Thorne, below, for example).

${ }^{32}$ Thorne (2002). See also Dowd (2010: 351).

${ }^{33}$ Warren-Heys (2010).

${ }^{34}$ Schwyzer (2004).
} 
memory includes a degree of forgetting. ${ }^{35}$ This can be mapped out on an ideological scale, making assertions about the underlying beliefs of a society as a whole. It can also be individualised: the diversity of the characters of Henry $V$ might guide us towards the recognition that what Fluellen remembers and forgets as he composes some sort of allegiance and affiliation is different from what Jamy, or Exeter, or Henry remembers and forgets.

Mind-wandering in Shakespeare, like mind-wandering in cognitive science, is associated with the stories individuals tell about themselves. Shakespeare finds a variety of ways to reveal and explore it. Sometimes the space for mind-wandering is there, onstage, palpable for us to observe. Sometimes it lies with the audience, a feeling that somehow the dramatic tension has slackened, necessarily, to give some room for inward manoeuvre. It is not that, for example, the Porter scene in Macbeth is without value (as entertainment and as a form in which various thematic interests are sharpened); nevertheless, it affords an interval in which the enormity of regicide and usurpation can be processed. This is not comic relief; this space is always full. The scene between Pistol and the French soldier (Henry $V$, 4.4) gives a mostly humorous view of the sordid, venal side of the battlefield. It is given an edge by the character of the Boy, who reveals his plan to stay with the 'luggage of the camp' (4.4.74-5); in retrospect this turns out to mean that he ends up among those killed by the French assault. The exchange also gives the audience space for some thinking between key causes and consequences.

There are other scenes of this sort, other cases where, even though there are things to engage and occupy an audience, there is a shift in the dramatic centre of gravity such that wandering minds have a chance to fill in gaps. Another scene in the same act features the comic argument between Fluellen and Williams over the latter's glove. Again this is part of the richness of the play and the fullness of its vision of war. However, there must be some degree to which the gap between Henry declaring himself 'not angry ... / Until this instant' (4.7.55-6), and the moment where the dead are counted (4.8.73), is only partly filled, and there is space for some wandering thoughts. The clearest example of this phenomenon may come when Henry woos the French princess: again it is not that the scene is not absorbing or rewarding, but there is still a story elsewhere, the final turn resulting from the rest of the action, towards which minds could and should drift. We know the negotiations continue offstage, and that their outcome will determine a great deal; the wooing itself is a shadow of the real conquest. Even Katherine's acknowledgement of her own powerlessness, 'Dat is as it

\footnotetext{
${ }^{35}$ Baldo (1996). Baldo revisited this argument in Memory in Shakespeare's Histories: Stages of Forgetting in Early Modern England (2012). See also Baldo's “'Into a Thousand Parts”: Representing the Nation in Henry $V^{\prime}$ (2008), which further unfolds the political subtleties.
} 
shall please de roi mon père' (5.2.247), veils the powerlessness suffered also by her father.

The space for wandering minds is not only opened by scenes that offer to divert us from the serious national business. More interestingly, indeed, it seems to result from some of the play's most emphatic moments. The speech at the walls of Harfleur in 3.3 promises violence of an extreme kind:

The gates of mercy shall be all shut up,

And the flesh'd soldier, rough and hard of heart,

In liberty of bloody hand, shall range,

With conscience wide as hell, mowing like grass

Your fresh fair virgins and your flow'ring infants.

What is it then to me, if impious War,

Arrayed in flames like to the prince of fiends,

Do with his smirch'd complexion all fell feats

Enlink'd to waste and desolation?

What is't to me, when you yourselves are cause,

If your pure maidens fall into the hand

Of hot and forcing violation? (3.3.10-21)

Wood's essay on distraction, as was seen above, suggests that sometimes an excess of detail requires a turn away for the reader, or audience, to be immersed effectively. The gruesome threats might prompt a new view of the King, capable of such violence, or willing to exploit its energising effect. They may, on the other hand, prompt an audience to blur out the detail in favour of maintaining a positive view of the war, or the King, or the play. If there is any disorientation, there is also an anchor in the question Henry asks: 'what is't to me?' This is where a wandering mind tends, after all, but it is also a pointed moment. Later in the speech he asks another such question, primarily to the people of Harfleur, after another set of vile threats:

If not-why, in a moment look to see

The blind and bloody soldier with foul hand

Defile the locks of your shrill-shriking daughters;

Your fathers taken by the silver beards,

And their most reverend heads dash'd to the walls;

Your naked infants spitted upon pikes,

Whiles the mad mothers with their howls confus'd

Do break the clouds, as did the wives of Jewry

At Herod's bloody-hunting slaughter-men.

What say you? (3.3.33-42)

The question resonates: how will it be incorporated into narratives of self and nation, allegiance and affiliation, and in what ways does an audience work with the speech's consequences, whether seeing it from the perspective of the town's inhabitants or of 
Henry's army? Although the tone and situation are very different from the Salic Law speech, this is another example of politics in action, of consent operating through explicit and implicit means.

In the 'band of brothers' speech Henry offers to include all listeners. $\mathrm{He}$ proposes a story they can tell themselves about the future, and that they can tell themselves in the future about the past. It even gives them words they can see themselves speaking:

This day is call'd the feast of Crispian:

He that outlives this day, and comes safe home, Will stand a' tiptoe when the day is named, And rouse him at the name of Crispian.

He that shall see this day, and live old age, Will yearly on the vigil feast his neighbours, And say 'To-morrow is Saint Crispian.'

Then will he strip his sleeve and show his scars, And say 'These wounds I had on Crispin's day.' (4.3.40-8)

The use of pronouns in the speech is skilful. Henry invokes ' $I$ ' and 'we' emphatically, and offers this separated 'he' as something to aspire to. He defines the shape of a daydream that his listeners onstage can inhabit, and perhaps their situation gives them few appealing alternatives. What this speech compels, perhaps, is both active assent and some corroborative work from those aspects of thinking, onstage and offstage, that perform the essential work of putting an idea of selfhood into a narrative that links the past and the future.

The play opens up spaces to think about how the wandering minds of the audience and characters will turn in relation to the political tensions of the play. Its central character turns out to be a kind of genius, and a kind of monster, when it comes to telling stories of himself at the heart of these tensions. His night-time excursion as Harry Le Roi is an embodied sort of mind-wandering, enabling him to have a conversation in which the place of the King - of himself - in moral and political narratives is explored. The assumed persona is able to engage in questions that move from 'what if?' to 'who am I?' His long soliloquy in 4.1 maps interestingly onto the world of the daydream. There are some soliloquies that resemble the work of the drifting mind, processing and organising self and world and time, inattentive to the surrounding situation; there are others that entirely do not, because they seem rhetorically wrought and designed for the outward occasion. Many are somewhere in between. In 4.1 there is a revealing moment when Henry's thinking finds its way to an underlying anxiety: 


\author{
Not to-day, O Lord, \\ $\mathrm{O}$, not to-day, think not upon the fault \\ My father made in compassing the crown! \\ I Richard's body have interred new, \\ And on it have bestow'd more contrite tears \\ Than from it issued forced drops of blood. (4.1.292-7)
}

This strong turn towards one facet of Henry's narrative might look like a daydream discovery; this is where we actually get somewhere, and the mind-wandering finds its destination. This is an oversimplification, because the content of the earlier speech is itself pertinent and interesting, especially for an audience with a stake in understanding the nature of monarchy. However, the sense that Henry has a loose thought to reorganise is pressing.

Elsewhere he shows a remarkable ability, and tendency, to put himself at the heart of the story. He takes things personally: the betrayal by Scrope, and the Dauphin's gift of tennis balls, would rile any prince, but they strike him with particular strength. In return, he is vengeful, unforgetting, having incorporated these causes thoroughly into himself. As in the Henry IV plays, he is a wanderer. Physically and mentally he drifts off, is absent, tries things out; and as in the Henry IV plays, he has unusual clarity in placing himself at the heart of events, in asserting the absoluteness of himself as the meaningful focus of events. These characteristics seem divergent in some ways, but not in the context of a modern understanding of mind-wandering. The King is the arch example of a tendency in the play to open up and explore the capacity of the mind to compose crucial stories of the self in the past, present, and future.

Much Ado About Nothing shares with Henry $V$ an interest in what happens when our minds leave the immediate moment and begin to construct stories about the past, present, and future. The reason for considering them as a pair is mostly to highlight that Shakespearean mind-wandering pertains both to the political and to the personal. However, the two plays are written in close chronological proximity, in 1598-9, possibly one after the other. The phenomena being explored here are by no means restricted to this moment in Shakespeare's career, but it is suggestive nonetheless that two such thoughtful investigations of what minds do, when they are not attentive to the immediate, should have been written so closely together. They have another important thing in common, which is that the inward stories that arise from mindwandering are not necessarily good for those involved: it is far from clear that war, and love, are as right for the individuals as they are right for society, ideology, or genre. 
In Much Ado About Nothing mind-wandering is multilayered. The awareness that there is another story to be told, a rearrangement of people and feelings that would be to their collective benefit, is simmering at the very beginning of the play. We know that Beatrice and Benedick will end up together. In spite of the comic interplay Much Ado features so prominently and effectively, it unites audience and characters in a daydream-like understanding that there is another plot waiting to emerge. Claire McEachern dares to say that progress in the play can become tedious at times. Modern productions, she says, understandably cut some of the scene (3.3) between Dogberry and the Watch. ${ }^{36}$ This could be a matter of changing taste, in that the first audiences may have had a greater appetite for word-play of Dogberry's kind; but perhaps not entirely so. McEachern acknowledges the unusualness of the play's configuration of thought and action:

Whereas many comedies spend their entire length embroiled in a crescendo of compounded confusion, Much Ado maintains a seeming innocence for two-thirds of its length. Or rather, while its participants are embroiled in the psychic obstacles which provide the comic oyster with its grit, they do not know they are embroiled until 4.1. ${ }^{37}$

There is a level at which this ignorance persists, but there is another level at which the characters and the audience are mulling over better configurations of people. An underlying pressure in the direction of a romantic conclusion is close to being explicit even at the beginning of the play. Kiernan Ryan goes further than McEachern in arguing that the play's 'essence' might be comprehended while the audience is 'distracted':

Time and again, the cloak of comic relief or aimless dialogue allows [Shakespeare] to distil the essence of what's at stake in the play, while the audience's mind and his own are off-guard or at ease, distracted from the issues that overtly drive the protagonists' more prominent exchanges. It's as if his relaxing of the conscious authorial control such exchanges demand releases subconscious intuitions of what lies beneath them, subliminal insights that find condensed expression in absurd digressions and impromptu quibbling. The transmission of those insights to the audience is all the more effective for being subliminal and oblique, for steering us inadvertently towards the heart of the matter. ${ }^{38}$

This passage starts from psychoanalytic-style language of the 'subconscious' and the 'subliminal', but nevertheless sees a characteristic in the play that is compatible with the world of the wandering mind. The key question is how the play creates moments of need and opportunity for the mind to wander 'inadvertently', and with what effects.

\footnotetext{
${ }^{36}$ McEachern (2005: 75).

${ }^{37}$ McEachern (2005: 59). See also pp. $61-6$ on the role of repetition in the play.

${ }^{38}$ Ryan (2009: 172).
} 
The quickfire dialogue between Beatrice and Benedick at the beginning of the play appears like it should be entirely attention-grabbing, but Shakespeare creates space around their dialogue for minds to wander. Those onstage and off may even imply at times that their conflict is a smokescreen, veiling or translating the underlying story. Furthermore, there are signs that this captivating action might actually be something to which attention could or should not be paid. The opening scene of the play gives us a series of clues in the ways that the Messinans talk about their two sparring friends. An early sign comes when Hero explains to the messenger the identity of the 'Signior Mountanto' asked after by Beatrice: 'My cousin means Signior Benedick of Padua' (1.1.35-6). This could be delivered in a number of tones, but it is at least clear that Hero does not have an appetite to extend what could have been the Messenger's amusing confusion. The joke is cut off too soon, but too late for Hero, who has already had enough.

The crackling exchange that follows the first appearance of Beatrice and Benedick includes a hint of its own undoing, when she says 'I wonder that you will still be talking, Signior Benedick, nobody marks you' (1.1.116-17). The play depends to some extent on the audience wanting plenty more 'talking' from both of them, but there is a subtle challenge to the whole play here: this routine is an old one, perhaps now an outmoded one. ${ }^{39}$ Much Ado About Nothing needs to capture the vivacity of the 'merry war' quickly so its unravelling can take place, but perhaps the play takes a risk by suggesting that it is past its prime. Other speakers offer related hints. After Beatrice's tonally complex parting comment, gesturing back into a shared past we know little about ('You always end with a jade's trick, I know you of old', 1.1.144-5), Don Pedro says to Leonato 'That is the sum of all' (1.1.146). This is a reference to the outcome of the battle, which he has been summarising, but it serves somewhat as a brush-off to the comic exchange. Don Pedro's slight, probably genial, impatience comes through later as well: 'you will temporize with the hours', he says (1.1.274-5), telling Benedick that in time (that is, soon enough) he will become less sharp. Don Pedro's urgent efficiency is evident when he develops his plan to woo Hero on Claudio's behalf, 'In practice let us put it presently' (1.1.328). To Claudio, indeed, he promises eloquence in a double-edged way: 'Thou wilt be like a lover presently / And tire the hearer with a book of words' (1.1.306-7). He wants to bring people together, 'presently', but he does not want to hear them talk about it; this observation sets an interesting tone for the comic interplay between Beatrice and Benedick. One of the play's most famous features, the couple's dazzling repartee, has lost its moment; perhaps no production, or reading, should go too far in that direction. However, it is suggested by other characters, with good reason, that Beatrice and Benedick would be better off talking less and recognising their true feelings more. They need their minds to wander onto

${ }^{39}$ On 'outmodedness' and love in Shakespeare, see Vasiliauskas (2015). 
other matters; their friends' minds are wandering there, and interesting spaces are being opened up for the audience to do the same.

Momentary feelings of dramatic redundancy might cause a moment of mindwandering. This might be conscious and deliberate, because, while the Watch is fumbling, a cruel plot is being put into action. Shakespeare seems to acknowledge and work with that possibility by disarming the audience's confidence in its sense of time. It comes, I think, as a surprise that the deception of Claudio has already taken place when Conrade and Borachio enter. It comes as a surprise also that Dogberry and the Watch recognise so quickly what has happened. The Watch is full of intention and purpose, but Dogberry urges him to let things go; one of the word-confusions ('be vigitant', 3.3.94) turns on a key word, alert attention as opposed to a wandering mind. The sense that attention could be drawn elsewhere is matched by attention-related nuances in the scene.

There are some vivid descriptions of the stillness and silence that fall when the truth strikes. When the Friar imagines what will happen when Claudio realises his error, he describes the discovery as curiously slow:

So will it fare with Claudio:

When he shall hear she died upon his words,

Th' idea of her life shall sweetly creep

Into his study of imagination. (4.1.222-25)

The phrase 'study of imagination' could be taken in various senses; one of these, among the more pertinent, is that it describes what it is like to process striking news into its full subjective importance. ${ }^{40}$ The slowness shows how strange the temporality of thought can be in Much Ado: should he not be struck suddenly, not 'sweetly'? When Claudio and Don Pedro are convinced of their error, the Friar's prediction comes back to mind:

Don Pedro Runs not this speech like iron through your blood?

Claudio I have drunk poison whiles he utter'd it. (5.1.245-6)

The slow movement that might be conceived in response to the idea of 'poison', and surely is in response to the 'iron through your blood', is at odds with the swift two-line exchange, even if we allow for momentous pauses. Nevertheless, again there is an interest in a process of incorporating bad news, just as there is in receiving good news:

\footnotetext{
${ }^{40}$ In her edition McEachern glosses this phrase as 'imaginative reflection, memory', but there is probably at least some contribution from OED, 'study, $n$.', 1, 'a state of contemplation or musing; a state of mental abstraction, a reverie'. The only other hit in Early English Books Online for the phrase, in Marcus Tullius Ciceroes Thre Bokes of Duties, trans. Nicholas Grimald (Cicero 1556: A4v), has this sense in mind: 'it commeth to passe, that the minde in advising is haled to and fro, and it bringeth a perplexed studie of imagination'. However, Shakespeare does not use the noun with this sense anywhere else.
} 


\begin{abstract}
Beatrice Speak, Count, 'tis your cue.
Claudio Silence is the perfectest herald of joy; I were but little happy, if I could say how much! Lady, as you are mine, I am yours. I give away myself for you, and dote upon the exchange.

Beatrice Speak, cousin, or (if you cannot) stop his mouth with a kiss, and let not him speak neither.

Don Pedro In faith, lady, you have a merry heart.

Beatrice Yea, my lord. I thank it - poor fool, it keeps on the windy side of care. My cousin tells him in his ear that he is in her heart.

Claudio And so she doth, cousin. (2.1.305-17)
\end{abstract}

Beatrice expects a response to be expressed outwardly, to be offered into the world for commentary. Claudio and Hero have two alternatives, neither of which quite plays the theatrical game that Beatrice so fulsomely, and so self-defeatingly, does. One is a whisper 'in his ear', private speech; the other is silence, and while there is no specific clarification as to how the lovers should behave at this point, it seems in keeping for them to be pausing. This is not the same as saying their minds are wandering, but the dramaturgy places them rather less in the moment than before, and in a state where, it might be inferred, they can do the work Beatrice and Benedick shy away from, acknowledging what this new narrative of self and other might lead to.

The society of Messina is not wholly benign. Patriarchal and other anxieties stalk the action, emerging violently at times, as when Leonato himself decides so quickly to believe the stories about his daughter. These might be thought of as political, as in Elliot Krieger's description of the struggles of the ruling class in a changing world, or they might be seen in relation to a broader sense that the play portrays a dead patriarchal order struggling to mean anything, as in Simon Palfrey's account:

Much Ado has a curious dynamic, in which each scene feels strangely paralysed in its moment, not so much terror-struck as pointless, an evacuated repetition of routines long ago fixed. ... But then, rumbling just apart from these surface conventions, we get things that are less easily accommodated, things we perhaps know as a fact but put to one side, or witness happening but do not know quite where to file, and so again put to the side, for a future occasion. ${ }^{41}$

What Palfrey has in mind are the wars that inhabit the fringes of the action, the misogyny of the plots and tricks, the sadness of lost loves, bitterness and jealousy of various kinds. These might be thought of as inhibitions on happy social life, and they are also sources of distraction, that might haunt wandering minds as they try to compose good stories of themselves in a troubled environment.

${ }^{41}$ Palfrey (2014: 282-3) and Krieger (1979). 
Critics have uncovered a variety of problems and mismatches in the thought processes of the play. Nova Myhill, for example, has explored how misperceptions (such as Claudio's fear that Don Pedro may be wooing Hero on his own behalf) are sometimes shared with the audience; the texture of dramatic irony is not a comfortable one. ${ }^{42}$ Paul Innes has observed a generational difference, in that members of the older generation, sometimes, manage to avoid making the same mistakes as the younger generation: the Friar and Dogberry are the best examples, while Leonato is a contentious one, who is at least easily persuaded back into faith in Hero. ${ }^{43}$ Gavin Edwards has portrayed an interesting quality in the interaction of minds and stories in Much Ado; they do not always corroborate one another. In his view, Beatrice discovers a new story of love, not one latent in herself; 'maiden pride, adieu' is a true departure ${ }^{44}$ Edwards describes resistance to innovation written into characters: 'the power of this scene [the first, failed wedding] may partly derive from a subliminal feeling that the actor playing Claudio has somehow refused to follow Shakespeare's script' (289). Overall, the play is 'much preoccupied with anticipation, retrospection, and the narrative ordering of human life' (278), which it has in common with human mind-wandering.

The progress of Beatrice and Benedick from 'merry war' to love runs in parallel with their progress from attentiveness to distraction; this could be rephrased to say that they finally allow their minds to wander and thereby they let themselves reframe their own stories. The scenes in which they are made to overhear accounts of feelings are perfectly configured to isolate them in situations where they are attentive to things being said, but unable to respond. In that passive gap lies the chance for a mind to race, to aim explicitly at certain thoughts but to be blindsided by others. Perhaps a dramatic character, more than an everyday person, can seem especially inward-turned when not speaking. During Benedick's equivalent scene (2.3), an atmosphere for mind-wandering may be enhanced by the presence of a song (an interlude, a diversion, a time to mull things over), about which there is word-play focusing on the word 'note'. It hardly needs to be said that the play's work with the word and idea of 'noting', even in its title, means that the question of attention, which is present in key senses of 'note', is a recurring one. Benedick's soliloquy, about love and why Claudio is 'such a man' as to fall for it (2.3.220-46), might look (as soliloquy did at times in Henry $V$ ) like a form in which to mind-wander; except that this rather studied performance of musing actually keeps him away from the eventual realisations that come with distraction. Whatever he has been doing while thinking over the things he hears, he

\footnotetext{
${ }^{42}$ Myhill (1999). See also Guéron (2015).

${ }^{43}$ Innes (2014).

${ }^{44}$ Edwards (1991).
} 
reaches a markedly quick conclusion: Beatrice loves him, he must love her, it all makes perfect sense when you just let yourself submit to not thinking about it directly.

Once they have decided they are in love, both Beatrice and Benedick are unable to maintain a scintillating witty performance. When they are happy, they are less interesting, or at least less focused. This distraction is loveable. In 3.4 Beatrice finds herself 'ill' and 'sick' as she is comprehensively outwitted by Margaret (at least in that she cannot find the energy, or the engagement, to compete). Benedick sings bad songs, and cannot even finish those, before Beatrice arrives in 5.2. Then they are both joined by Ursula, who delivers an abrupt summary of the big news:

Ursula Madam, you must come to your uncle, yonder's old coil at home. It is prov'd my Lady Hero hath been falsely accus'd, the Prince and Claudio mightily abus'd, and Don John is the author of all, who is fled and gone. Will you come presently?

Beatrice Will you go hear this news, signior?

Benedick I will live in thy heart, die in thy lap, and be buried in thy eyes; and moreover I will go with thee to thy uncle's. (5.2.95-104)

Both reactions seem significant. Beatrice turns to Benedick: the moment of triumph does not seem to strike her individually. Benedick turns to Beatrice, and the immediate moment is quickly turned into an afterthought ('moreover'). Having spent so much time alert to the surface of events, they are now in a wandering state, at one remove even from the news about Hero.

It has been possible to describe a meaningfulness for a modern-looking wandering mind in the world of Much Ado. It was also hazarded that the audience is invited at the very start of the play, counter-intuitively, to feel that it should not over-invest in the conversational sparks of Beatrice and Benedick. The genial inattentiveness of the Messinans reappears later in the play in the form of an interesting verbal tic present in more than one character:

Beatrice What should I do with him? dress him in my apparel and make him my waiting-gentlewoman? He that hath a beard is more than a youth, and he that hath no beard is less than a man: and he that is more than a youth is not for me, and he that is less than a man, I am not for him: therefore I will even take sixpence in earnest of the berrord [that is, bear-ward], and lead his apes into hell.

Leonato Well then, go you into hell?

Beatrice No, but to the gate, and there will the devil meet me, like an old cuckold with horns on his head, and say 'Get you to heaven, Beatrice, get you to heaven; here's no place for you maids.' So deliver I up my apes, and away to Saint Peter. For the heavens, he shows me where the bachelors sit, and there live we as merry as the day is long. 
Antonio [To Hero] Well, niece, I trust you will be rul'd by your father.

Beatrice Yes, faith, it is my cousin's duty to make cur'sy and say, 'Father, as it please you.' But yet for all that, cousin, let him be a handsome fellow, or else make another cur'sy and say, 'Father, as it please me.'

Leonato Well, niece, I hope to see you one day fitted with a husband. (2.1.34-58)

The three instances of 'well' are all different, but to varying degrees they seem to register a sense that this conversation is not moving at the right rate or in the right direction. Of course, they could all be performed as delighted rejoinders. However, Leonato's 'well then' might suggest that he is joining in out of weary, habitual, politeness; Antonio's turn to Hero might be a wish to change focus; Leonato's third 'well' seems even more like an attempt to stop Beatrice. As the OED says in its entry ('well, $a d v$. and $n .4$ '), it is 'frequently used only as a preliminary or resumptive word', but is also 'a discourse marker, often expressing an emotion such as surprise, indignation, resignation, or relief'. Elsewhere Leonato does seem more agitated as he uses it:

$\begin{array}{ll}\text { Don Pedro } & \text { We have some haste, Leonato. } \\ \text { Leonato } & \text { Some haste, my lord! Well, fare you well, my lord. } \\ & \text { Are you so hasty now? Well, all is one. } \\ \text { Don Pedro } & \text { Nay, do not quarrel with us, good old man. (5.1.47-50) }\end{array}$

Here of course there is no sense that he is tactfully shifting focus; rather he is commenting indignantly on Don Pedro's wish to shift focus. In one of his other uses, he is more clearly proposing a positive move into action:

Antonio Well, I am glad that all things sorts so well.

Benedick And so am I, being else by faith enforc'd

To call young Claudio to a reckoning for it.

Leonato Well, daughter, and you gentlewomen all,

Withdraw into a chamber by yourselves,

And when I send for you, come hither masked. (5.47-12)

This is 'well' as 'right then', moving on from Benedick's personal reflection to the creation of the climactic scene. The idea that other characters have had enough of Beatrice and Benedick is a difficult, self-defeating one for a dramatist to work with, but it offers a way of deepening the significance of many moments in the play, and of course it does not disallow much of the energy and entertainment-value in their exchanges.

The word 'well' is spoken by several other speakers in this colloquial, conversational, way: Dogberry in particular, the Watch, Margaret, and Don Pedro. It is a common word in Shakespeare, and not all uses offer anything other than a little piece of 
linguistic glue. In Don Pedro's case, however, it might be possible to see 'well' as a verbal habit of the older generation spectating on the follies of youth:

$\begin{array}{ll}\text { Benedick } & \begin{array}{l}\text { Prove that ever I lose more blood with love than I will get again } \\ \text { with drinking, pick out mine eyes with a ballad-maker's pen, and } \\ \text { hang me up at the door of a brothel-house for the sign of blind } \\ \text { Cupid. }\end{array} \\ \text { Don Pedro } & \begin{array}{l}\text { Well, if ever thou dost fall from this faith, thou wilt prove a } \\ \text { notable argument. }\end{array} \\ \text { Benedick } & \begin{array}{l}\text { If I do, hang me in a bottle like a cat, and shoot at me, and he that } \\ \text { hits me, let him be clapp'd on the shoulder, and call'd Adam. }\end{array} \\ \text { Don Pedro } & \begin{array}{l}\text { Well, as time shall try: 'In time the savage bull doth bear the yoke.' } \\ \text { not }\end{array}\end{array}$ $(1.1 .250-61)$

This exchange comes in the very first scene, and it requires the same delicate handling as the one between Leonato and Beatrice. Don Pedro's 'well' could be performed with geniality or pleasure, or with a hint that he has had his fill of Benedick's wit, and the routinised back-and-forth is wearing a little thin. This word 'well', then, subtly draws us away from the witty surface, and points towards the wandering depths.

In relation to national politics, and in relation to personal relationships, Henry $V$ and Much Ado About Nothing, in their different ways, find unexpected roles for wandering minds. Considering the qualities of mind-wandering being discussed here could add a further dimension to the mental worlds of other plays too. The approach also intersects in various ways with existing criticism. For example, it could be put into fruitful conversation with other treatments of the unseen and unrepresented in Shakespeare. At the forefront here would be the work of Lorna Hutson, who has described the importance of the things that must be inferred from what we see onstage ("past or distant occurrences, implied motives, habitual actions'). ${ }^{45}$ Hutson turns to law rather than psychology for a context in which the piecing together of unseen causes can be grounded. Alongside this, at certain moments, it might be possible to see the potential of more personal, more self-oriented, stories to play a part. An interest in mindwandering could also contribute to the exploration of the 'sense of an ending' in fiction inspired by Frank Kermode. ${ }^{46}$ It offers the possibility of mechanisms and rationales for the sort of predictive, ongoing, work that defines and modifies hopes and expectations.

\footnotetext{
${ }^{45}$ Hutson (2015: 5).

${ }^{46}$ Kermode (1967).
} 
The modern psychology of mind-wandering is part of a new science of the mind that entails a shift of attention from modules and representations to networks, from storage and access to construction and creation, from unitary selves to dialogic and narrative ones. This new science of the mind seems like a literary science, in which stories and echoes and performances come to the fore. It also seems like a Shakespearean science: the importance of time and timing; the self as a narrative or a network, dependent on others, rather than an achieved concept, complete in itself; the way that thoughts and words and bodies interact; the way that social life, from couples to nations, is crucial to the individual but also constructed differently for each individual mind. Corballis's book on mind-wandering is less explicitly in this field than the work of, say, Charles Fernyhough, whose books on memory and inner voices are models of how one can write about minds and stories in subtle and fruitful interactions. ${ }^{47}$ Nevertheless, there is a special liveliness in the exchange - an exchange which can be illuminating in both directions - between the bold conclusions drawn from experiments, brought to life in diagrams of networked activation in fMRI scans, and Shakespeare's own experiments with mind-wandering.

\section{REFERENCES}

Adorno, Theodor W. (2001), 'On the Fetish Character in Music and the Regression of Listening', in The Culture Industry: Selected Essays on Mass Culture, ed. J. M. Bernstein (London, Routledge), $29-60$.

Anderson, Benedict (1983), Imagined Communities: Reflections on the Origin and Spread of Nationalism (New York, Verso).

Axton, Marie (1977), The Queen's Two Bodies: Drama and the Elizabethan Succession (London, Royal Historical Society).

Baldo, Jonathan (1996), 'Wars of Memory in Henry V', Shakespeare Quarterly, 47: 132-59. https://doi.org/10.2307/2871099

Baldo, Jonathan (2008), "Into a Thousand Parts": Representing the Nation in Henry V', English Literary Renaissance, 38: 55-82. https://doi.org/10.1111/j.1475-6757.2008.00117.x

Baldo, Jonathan (2012), 'Wars of Memory in Henry V', in Memory in Shakespeare's Histories: Stages of Forgetting in Early Modern England (London, Routledge), 102-30.

https://doi.org/10.4324/9780203142127

Baldo, Jonathan (2014), 'Shakespeare's Art of Distraction', Shakespeare, 10: 138-57. https://doi.org/10.1080/17450918.2013.806579

Benjamin, Walter (1999), 'The Work of Art in the Age of Mechanical Reproduction', in Illuminations, ed. Hannah Arendt, trans. Harry Zorn (London, Pimlico).

Bennett, Alice (2018), Contemporary Fictions of Attention: Reading and Distraction in the Twenty-first Century (London, Bloomsbury). https://doi.org/10.5040/9781474282604

${ }^{47}$ Fernyhough (2012, 2016). 
Bevis, Matthew (2017), 'In Search of Distraction: The Rewards of the Tangential, the Digressive, and the Dreamy', Poetry Magazine.

https://www.poetryfoundation.org/poetrymagazine/articles/144656/in-search-of-distraction

Blakemore Evans et al. (eds), G. (1997), The Riverside Shakespeare, 2nd edn (Boston, MA, Houghton Mifflin).

Burton, Robert (1621), The Anatomy of Melancholy (London, Henry Cripps). https://doi.org/10.1093/oseo/instance.00006619

Callard, F., Smallwood, J., Golchert, J. \& Margulies, D. S. (2013), 'The Era of the Wandering Mind? Twenty-first Century Research on Self-generated Mental Activity', Frontiers in Psychology, 4: article 891. https://doi.org/10.3389/fpsyg.2013.00891

Cartwright, Kent (1991), Shakespearean Tragedy and its Double: The Rhythms of Audience Response (College Park, PA, Pennsylvania University Press).

Cave, Terence (2007), How to Read Montaigne (London, Granta).

Cicero (1556), Marcus Tullius Ciceroes Thre Bokes of Duties, trans. Nicholas Grimald (London, Richard Tottel).

Corballis, Michael C. (2015), The Wandering Mind: What The Brain Does When You're Not Looking (Chicago, IL, University of Chicago Press). https://doi.org/10.7208/chicago/9780226238753.001.0001

Dawson, Anthony (1988), Watching Shakespeare: A Playgoer's Guide (Basingstoke, Palgrave Macmillan). https://doi.org/10.1007/978-1-349-19362-2

Dawson, Anthony B. \& Yachnin, Paul (2001), The Culture of Playgoing in Shakespeare's England: A Collaborative Debate (Cambridge, Cambridge University Press).

Dowd, Christopher (2010), 'Polysemic Brotherhoods in Henry V', Studies in English Literature 15001900, 50: 337-53. https://doi.org/10.1353/sel.0.0099

Edwards, Gavin (1991), 'Anticipation and Retrospect in Much Ado About Nothing', Essays in Criticism, 41: 277-90. https://doi.org/10.1093/eic/XLI.4.277

Fernyhough, Charles (2016), Pieces of Light: The New Science of Memory (London, Profile Books).

Fernyhough, Charles (2016), The Voices Within: The History and Science of How We Talk to Ourselves (London, Profile Books \& Wellcome Collection).

Fornito, Alex, Harrison, Ben J., Zalesky, Andrew \& Simons, Jon S. (2012), 'Competitive and Cooperative Dynamics of Large-scale Brain Functional Networks Supporting Recollection', Proceedings of the National Academy of Sciences of the United States of America, 109(31): 12788-93. http://www.pnas.org/content/109/31/12788; https://doi.org/10.1073/pnas.1204185109

Gilbert, Sam J., Dumontheil, Iroise, Simons, Jon S., Frith, Chris D. \& Burgess, Paul W. (2017), 'Comment on "Wandering Minds: The Default Network and Stimulus-independent Thought", Science, 317(5834): 43. https://doi.org/10.1126/science.1140801

Greenblatt, Stephen (1988), Shakespearean Negotiations: The Circulation of Social Energy in Renaissance England (Berkeley, CA, University of California Press).

Guéron, Claire (2015), 'Rumour and Second-hand Knowledge in Much Ado About Nothing', in The Circulation of Knowledge in Early Modern Literature, ed. Sophie Chiari (Farnham, Kent, Ashgate), 93-103.

Gurr, Andrew (1987), Playgoing in Shakespeare's London, 2nd edn (Cambridge, Cambridge University Press), 45-9.

Gurr, Andrew (2009), The Shakespearean Stage 1574-1642, 4th edn (Cambridge, Cambridge University Press), 275-82. https://doi.org/10.1017/CBO9780511819520

Gurton-Wachter, Lily (2013), “"Ever on the Watch”: Wordsworth's Attention', Studies in Romanticism, 52: $511-35$.

Hutson, Lorna (2015), Circumstantial Shakespeare (Oxford, Oxford University Press). https://doi.org/10.1093/acprof:oso/9780199657100.001.0001 
Innes, Paul (2014), 'Sensory Confusion and the Generation Gap in Much Ado about Nothing', Critical Survey, 26: 1-20. https://doi.org/10.3167/cs.2014.260201

Joyce, James (1939), Finnegans Wake (London, Faber and Faber).

Kermode, Frank (1967), The Sense of an Ending: Studies in the Theory of Fiction (Oxford, Oxford University Press).

Krieger, Elliot (1979), 'Social Relations and the Social Order in Much Ado About Nothing', Shakespeare Survey, 32: 49-61. https://doi.org/10.1017/CCOL0521227534.005

Lake, Peter (2016), How Shakespeare Put Politics on the Stage: Power and Succession in the History Plays (New Haven, CT, Yale University Press). https://doi.org/10.12987/yale/9780300222715.001.0001

Marno, David (2016), Death Be Not Proud: The Art of Holy Attention (Chicago, IL, University of Chicago Press). https://doi.org/10.7208/chicago/9780226416021.001.0001

McCarthy, Cormac (1985), Blood Meridian (New York, Random House).

McEachern, Claire (1996), 'Speaking in Common: Henry V and the Paradox of the Body Politic', in The Poetics of English Nationhood 1590-1612 (Cambridge, Cambridge University Press), 83-137.

McEachern, Claire (ed.) (2005), Much Ado About Nothing 3rd edn (London, Bloomsbury). https://doi.org/10.1017/CBO9780511704307.003

Montaigne, Michel de (1603), The Essayes or Morall, Politike and Millitarie Discourses, trans. John Florio (London, Edward Blount), 2T3r.

Myhill, Nova (1999), 'Spectatorship in/of Much Ado About Nothing', Studies in English Literature 1500 1900, 39: 291-311. https://doi.org/10.2307/1556167

North, Paul (2011), The Problem of Distraction (Stanford, CA Stanford University Press).

Palfrey, Simon (2014), Shakespeare's Possible Worlds (Cambridge, Cambridge University Press).

Palfrey, Simon \& Stern, Tiffany (2017), Shakespeare in Parts (Oxford, Oxford University Press).

Phillips, Natalie M. (2016), Distraction: Problems of Attention in Eighteenth-century Literature (Baltimore, MD, Johns Hopkins University Press).

Pye, Christopher (2015), The Storm at Sea: Political Aesthetics in the Time of Shakespeare (New York, Fordham University Press). https://doi.org/10.5422/fordham/9780823265046.001.0001

Rabkin, Norman (1977), 'Rabbits, Ducks, and Henry V', Shakespeare Quarterly, 28: 279-96. https://doi.org/10.2307/2869079

Rackin, Phyllis (1990), Stages of History: Shakespeare's English Chronicles (Ithaca, NY, Cornell University Press).

Ryan, Kiernan (2009), Shakespeare's Comedies (Basingstoke, Palgrave Macmillan).

Schooler. J. W. Smallwood, J., Christoff, K., Handy, T. C., Reichle, E. D. \& Sayette, M. A. (2011), 'Metaawareness, Perceptual Decoupling and the Wandering Mind', Trends in Cognitive Sciences, 15: 319-26. https://doi.org/10.1016/j.tics.2011.05.006

Schwyzer, Philip (2004), Literature, Nationalism, and Memory in Early Modern England and Wales (Cambridge, Cambridge University Press). https://doi.org/10.1017/CBO9780511483950

Seli, Paul, Risko, Evan F., Smilek, Daniel \& Schacter, Daniel L. (2016), 'Mind-wandering With and Without Intention', Trends in Cognitive Sciences, 20: 605-17. https://doi.org/10.1016/j.tics.2016.05.010

Smallwood, Philip (ed.) (2004), Players of Shakespeare: Essays in the Performance of Shakespeare's History Plays (Cambridge, Cambridge University Press).

Taylor, Gary (ed.) (2008), Henry V (Oxford, Oxford University Press).

Thorne, Alison (2002), 'Awake Remembrance of These Valiant Dead: Henry V and the Politics of the English History Play', Shakespeare Studies, 30: 162-87.

Tribble, Evelyn (2011), Cognition in the Globe: Attention and Memory in Shakespeare's Theatre (Basingstoke, Palgrave Macmillan).

Tribble, Evelyn (2015), 'Sight and Spectacle', in Shakespeare's Theatres and the Effects of Performance, eds Farah Karim-Cooper \& Tiffany Stern (London, Bloomsbury), 237-52. 
Tribble, Evelyn (2017), Early Modern Actors and Shakespeare's Theatre: Thinking with the Body (London, Bloomsbury).

Vasiliauskas, Emily (2015), 'The Outmodedness of Shakespeare's Sonnets', English Literary History, 82: 759-87. https://doi.org/10.1353/elh.2015.0026

Wang, Hao-Ting, Poerio, Giulia, Murphy, Charlotte, Bzdok, Danilo, Jefferies, Elizabeth \& Smallwood, Jonathan (2017), 'Dimensions of Experience: Exploring the Heterogeneity of the Wandering Mind', Psychological Science, 28: 1-16. https://doi.org/10.1177/0956797617728727

Warren-Heys, Rebecca (2010), “[R]emember, with Advantages”: Creating Memory in Shakespeare's Henry $V^{\prime}$, Journal of the Northern Renaissance, 2.

https://www.northernrenaissance.org/remember-with-advantages-creating-memory-in-shakespeareshenry-v/

Watzl, Sebastian (2017), Structuring Mind: The Nature of Attention and How It Shapes Consciousness (Oxford, Oxford University Press). https://doi.org/10.1093/acprof:oso/9780199658428.001.0001

Wood, Michael (2009), 'Distraction Theory: How To Read While Thinking of Something Else', Michigan Quarterly Review, 48(4). http://hdl.handle.net/2027/spo.act2080.0048.410

Wood, Michael (2018), Habits of Distraction (Brighton, Sussex Academic Press).

Woodcock, Matthew (2008), Henry V: A Reader's Guide to Essential Criticism (Basingstoke, Palgrave Macmillan).

Acknowledgements: I am grateful to all those who attended, and asked excellent questions, at the Globe and later in Oxford. Particular thanks are owed to those who kindly and insightfully commented on drafts of the essay: Kent Cartwright, Mary Thomas Crane, Esther Osorio Whewell, Evelyn Tribble, Ted Tregear, and the reader for the Journal of the British Academy.

To cite the article: Raphael Lyne (2020), 'Shakespeare and the wandering mind', Journal of the British Academy, 8: 1-27. DOI https://doi.org/10.5871/jba/008.001

Journal of the British Academy (ISSN 2052-7217) is published by The British Academy, 10-11 Carlton House Terrace, London, SW1Y 5AH www.thebritishacademy.ac.uk 
